\title{
Policy Responses to External Imbalances in Emerging Market Economies: Further Empirical Results
}

\section{CHORNG-HUEY WONG and LUIS CARRANZA*}

A bivariate vector-autoregression (VAR) model is used to test causal relations between the current account and the capital account in four emerging market economies. The results show that high capital mobility could be a major cause of current account instability. Therefore, macroeconomic policy to restore external balance must deal directly with capital inflows. The paper recommends making nominal exchange rate sufficiently flexible to avoid inconsistencies between shortrun and long-run real exchange rates; complementing credit tightening by fiscal restraint to reduce interest rate differentials; and strengthening reforms and surveillance of the financial system to prevent banks from excessive risk taking. [JEL C32, E61, F21, F32, F41]

he interrelations between the current account and the capital account in emerg-

ing market economies have changed dramatically since the beginning of the rapid globalization of capital markets in the late 1980s. Prior to globalization, when a country faced balance of payments difficulties, domestic macroeconomic and external sector policies generally focused on how to stabilize the current account. Access to international capital markets was regarded as a means of financing a country's current account deficits; hence, capital movements followed the changes in the current account position. Since the early 1990s, it has become

\footnotetext{
*Chorng-Huey Wong is Senior Advisor in the IMF Institute, and Luis Carranza was an Economist in the IMF Institute when the paper was prepared. The authors would like to thank Luis Catão, Enzo Croce, Graciana del Castillo, Susan George, Lorenzo Giorgianni, Celia Gonzalez, Nadeem Ul Haque, Qaizar Hussain, Mohsin Khan, Cheng Hoon Lim, Alejandro Lopez-Mejia, Ousmene-Jacques Mandeng, Saleh Nsouli, and Abdelhak Senhadji for their helpful comments.
} 
increasingly evident that, with the opening up of the capital account, capital movements themselves could be a major cause of current account instability, so that stabilizing the balance of payments has also come to include stabilizing the capital account.

At the theoretical level, a positive net capital inflow implies a higher stock of financial claims by the rest of the world against the residents and, hence, larger profit remittances and dividend and/or interest payments in the future. More important, under a flexible exchange rate regime, positive net capital inflows could cause the nominal and real exchange rates to appreciate. The resulting change in relative prices would positively affect demand for tradables relative to nontradables and production of nontradables relative to tradables, leading to current account deficits. If the country has a fixed exchange rate regime, sterilized intervention would push up domestic interest rates, allowing capital inflows to continue. In this case, the interaction between the two accounts is, at least in the short run, weakened by the avoidance of changes in relative prices and in monetary aggregates. If sterilization is incomplete, however, the more rapid monetary growth may increase the level of domestic absorption and domestic prices, including asset prices, which in turn may create deficits in the current account. This situation could deteriorate rapidly if domestic absorption involves a high degree of speculation and risk taking.

Section I discusses possible inconsistencies between short-run and long-run real exchange rates caused by capital account shocks. Section II tests the causality between the current and capital accounts for four countries-Argentina, Mexico, Philippines, and Thailand. The final section discusses the appropriate policy responses to large capital inflows, based on the empirical results. It complements what has become a standard policy package in dealing with large capital inflows, emerging from extensive discussions prior to the recent financial crises (e.g., Calvo, Leiderman, and Reinhart, 1993, 1994, and 1996; Khan and Reinhart, 1995; Montiel, 1995 and 1996; Montiel and Reinhart, 1997; and Schadler and others, 1993).

\section{Capital Account Shocks and Inconsistencies Between the Short-Run Exchange Rate and the Long-Run Exchange Rate}

In a standard framework used to analyze the effects of external shocks, it is usually assumed that (1) the foreign exchange market reacts more quickly than other domestic markets to external shocks, and (2) the current account is more responsive to changes in the real exchange rate than to changes in real interest rates, whereas the capital account, for a given expected exchange rate, could be equally responsive to both. Within this framework, it is generally observed that when capital account shocks take place, the short-run real exchange rate could move away from the long-run equilibrium real exchange rate. The composition, level, and use of capital inflows will determine whether, and to what extent, inconsistency exists between the short-run and the long-run real exchange rate.

To illustrate that the composition of capital inflows matters in determining the long-run equilibrium, two extreme cases are considered. First, assume that capital 
inflows are entirely in the form of foreign direct investment. The real exchange rate will tend to appreciate initially. Even though profit remittances abroad will subsequently increase, their negative effects on the current account could be more than compensated for by the likely positive effects of the increase in productivity and exports, resulting in a permanent appreciation of the long-run real exchange rate.

The second case is short-term capital inflows responding to a drop in interest rates in the rest of the world. As in the previous case, the real exchange rate will appreciate initially. When interest payments on the new borrowing are due, and assuming that the short-term capital has not contributed to an increase in productivity, the current account position will deteriorate, leading to a depreciation of the long-run equilibrium real exchange rate. At the same time, if sterilized intervention is not being pursued, domestic interest rates will tend to equalize with foreign interest rates.

Several observations can be made regarding the dynamics in the adjustment process emanating from an inflow of short-term capital. First, the long-run equilibrium real exchange rate will depend on agents' future actions; therefore, there is initially a high level of uncertainty about this variable. Second, if domestic interest rates are not fully flexible (because of noncompetitive behavior in the banking sector, for example), or if sterilized intervention is being pursued, in the short run there will be arbitrage opportunities for investors to exploit. This is true even when in the long run a more depreciated real exchange rate is expected because of the change in fundamentals. Third, unsustainable current account deficits would create pressure for nominal depreciation, which could affect investor confidence, leading to a reversal of capital flows. Finally, as shown in Montiel and Reinhart (1997), the policy response to the early wave of capital inflows will influence both the level and the composition of subsequent capital movements, with varying implications for domestic financial stability.

\section{Empirical Results}

\section{Causality Tests}

To provide evidence on the dynamic interactions between the current account and the capital account, we estimate a bivariate vector-autoregression (VAR) model for four emerging market countries (Argentina, Mexico, Philippines, and Thailand), and perform the Granger causality test using this model. ${ }^{1}$ According to this test, the capital account balance is said to cause the current account balance if the current account balance is significantly better predicted using the past values of both the current account balance and the capital account balance than using the past values of the current account balance alone.

All data used in this study are taken from the IMF's Economic Information System database. The period for the investigation is from the mid-1970s to the mid-1990s. During this period all four countries had large and volatile current account balances relative to GDP. All countries had been affected by the global-

${ }^{1}$ For this technique, see Granger (1969), Hamilton (1994), and Judge and others (1985). 
ization of capital markets and, consequently, had received sizable capital inflows during the 1990s.

For each country, the study analyzes two independent samples, with the first quarter of 1989 being the breaking point in the time series, ${ }^{2}$ which coincides with the structural change in the international capital markets. The time series used in the causality tests ends before the onset of the financial crisis, so this paper does not deal with crisis management. To make sure that the results of the causality tests are not spurious, we performed a test for unit roots. By and large, the unit-root assumption regarding the time series for both the current account balance and the capital account balance for all countries for the periods under investigation can be rejected at conventional significance levels.

\section{Argentina}

During the 1970s and 1980s, Argentina faced an extremely difficult external position. In the 1970s, high fiscal deficits, combined with real exchange rate appreciation, caused a steady deterioration in the current account. In the 1980s, the economy suffered from an excessive accumulation of external debt and severe debt-servicing difficulties. The stabilization plans undertaken in 1984-89 sought to obtain a competitive real exchange rate through a series of nominal devaluations to generate trade surpluses to service the external debt. However, these steps were not accompanied by sufficient fiscal restraint. As a result, the economy experienced a vicious circle of devaluation-inflation.

This situation is reflected in the causality tests performed. A VAR model with five lags was estimated for $1977-88 .^{3}$ Even though this sample period includes a subperiod (post-debt crisis) in which Argentina had no access to the international capital markets, test results show that the current account balance causes the capital account balance (see Table 1). ${ }^{4}$ For 1977-82, the statistical evidence of a causality running from the current account to the capital account is even stronger. 5 But for 1977-88, the tests support the hypothesis that the capital account balance does not cause the current account balance.

In the 1990s, Argentina experienced large capital inflows, attributable to the structural reforms launched in the late 1980s and early 1990s-privatization of

\footnotetext{
${ }^{2}$ The results are robust to changes in the breaking point.

${ }^{3}$ The appropriate lag length of each model was determined based on the Akaike information criterion (Akaike, 1973), according to which the optimal autoregressive order $q$ is chosen such that$$
\operatorname{AIC}(q)=\min \{A I C(j) \mid j=1, \ldots, N\},
$$

where

$$
A I C(j)=\ln \sigma^{2}(j)+2 K / T .
$$

Here $\sigma^{2}(j)$ is the maximum likelihood estimate of the residual variance, $K$ is the number of parameters, $j$ is the lag number, and $T$ is the number of observations.

${ }^{4}$ The number in parentheses represents the probability of type $I$ error.

${ }^{5} \mathrm{~A}$ model with six lags was estimated. The hypothesis that the current account balance does not cause the capital account balance is rejected (probability of type $I$ error $=0.02$ ), while the hypothesis that the capital account balance does not cause the current account balance is accepted (probability of type $I$ error $=0.17$ ). However, the results of this and other tests for the restricted sample period are not very robust.
} 


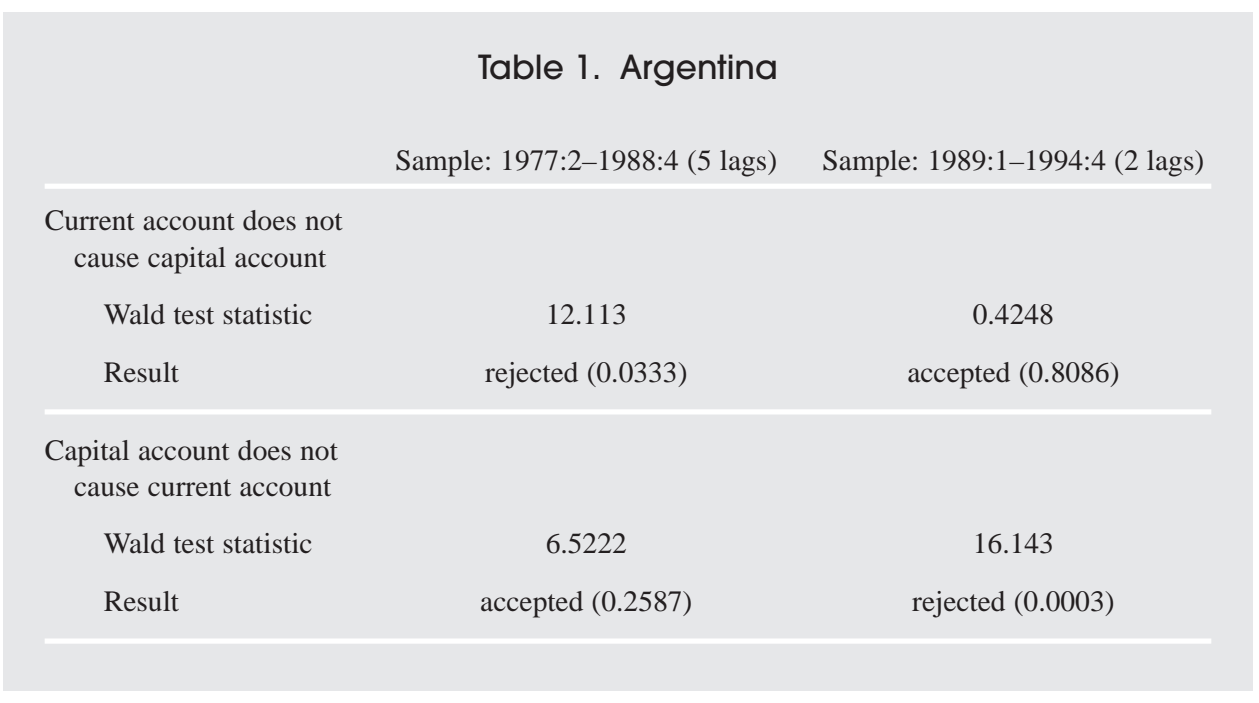

public enterprises, deregulation in capital and labor markets, trade liberalization, and restructuring of the public debt-and the new developments in the international capital markets. Because a currency board arrangement had been in place since March 1991, these capital inflows were reflected in the growth of the monetary base. At the same time, there were difficulties in controlling fiscal expenditures. The resulting increase in domestic demand and inflation produced an appreciation of the real exchange rate, further worsening current account deficits.

In Table 1, the Granger tests for 1989-94 provide strong evidence of a causality running from the capital account to the current account, but support the hypothesis that the current account balance does not cause the capital account balance.

\section{Mexico}

During the late 1970s and early 1980s, the Mexican government decided to increase its expenditure to stimulate economic growth. The resulting large fiscal deficits were financed mainly by external borrowing. As a result, over 1978-82 the ratio of external debt to GDP rose from 26 percent to 59 percent.

In 1982, Mexico's external debt crisis was triggered by a combination of rising world interest rates and falling oil prices, as well as a recession in the United States. Because of its subsequent exclusion from the international capital markets, Mexico was unable to continue expanding government spending through external financing. Fiscal restraint was thus the only option left to the government. The fiscal austerity measures and the real exchange rate depreciation contributed to the improvement of the current account balance. Nevertheless, despite several reschedulings of the external debt, large trade surpluses were required for debt servicing and repayment.

In December 1987, Mexico launched a stabilization program (the Pact of Economic Solidarity) to stop high inflation without causing a recession. The program consisted of a combination of fiscal and monetary tightening and wage-price 


\section{Table 2. Mexico}

Sample: 1979:4-1988:4 (3 lags) Sample: 1989:1-1994:3 (2 lags)
Current account does not
cause capital account
Wald test statistic
2.8168
1.0218
Result
accepted $(0.4207)$
accepted (0.6000)
Capital account does not
cause current account
Wald test statistic
1.5549
6.0804
Result
accepted $(0.6697)$
rejected $(0.0478)$

control. Beginning in February 1988, the exchange rate was used as a nominal anchor. Although the program succeeded in lowering inflation, a substantial appreciation in the real exchange rate ensued.

The causality tests performed for 1979-88 show a lack of causal relations between the current account and the capital account. Both null hypothesesthat the capital account balance does not cause the current account balance and that the current account balance does not cause the capital account balanceare accepted (see Table 2).

By 1989, the renegotiation of Mexico's external commercial debt had reduced both the debt stock and the debt service, but more important, Mexico had regained access to the international capital markets. From 1990 to 1993, Mexico experienced increasingly large capital inflows, particularly portfolio investment. The policy responses to the situation consisted of sterilized intervention; capital controls in the form of high liquidity requirements against and limits on banks' foreign currency liabilities; greater flexibility in the exchange rate through the introduction of the crawling exchange rate band; and structural reforms, including trade liberalization, market deregulation, and liberalization of capital outflows.

As a result of these measures, the real exchange rate strongly appreciated, causing large current account deficits. The higher foreign savings more than compensated for the reduction in domestic savings, explaining the increases in the ratios of both consumption and investment to GDP. During 1994, a series of internal and external factors caused the loss of confidence in the government's ability to maintain the nominal exchange rate, leading to a reversal of capital flows. On December 22, the exchange rate was allowed to float after several unsuccessful attempts to keep it within the band. ${ }^{6}$

\footnotetext{
${ }^{6}$ Several authors have discussed the Mexican crisis in detail, although with different interpretations (see, for example, Dornbusch, Goldfajn, and Valdes, 1995; Calvo and Mendoza, 1996; Sachs, Tornell, and Velasco, 1996).
} 


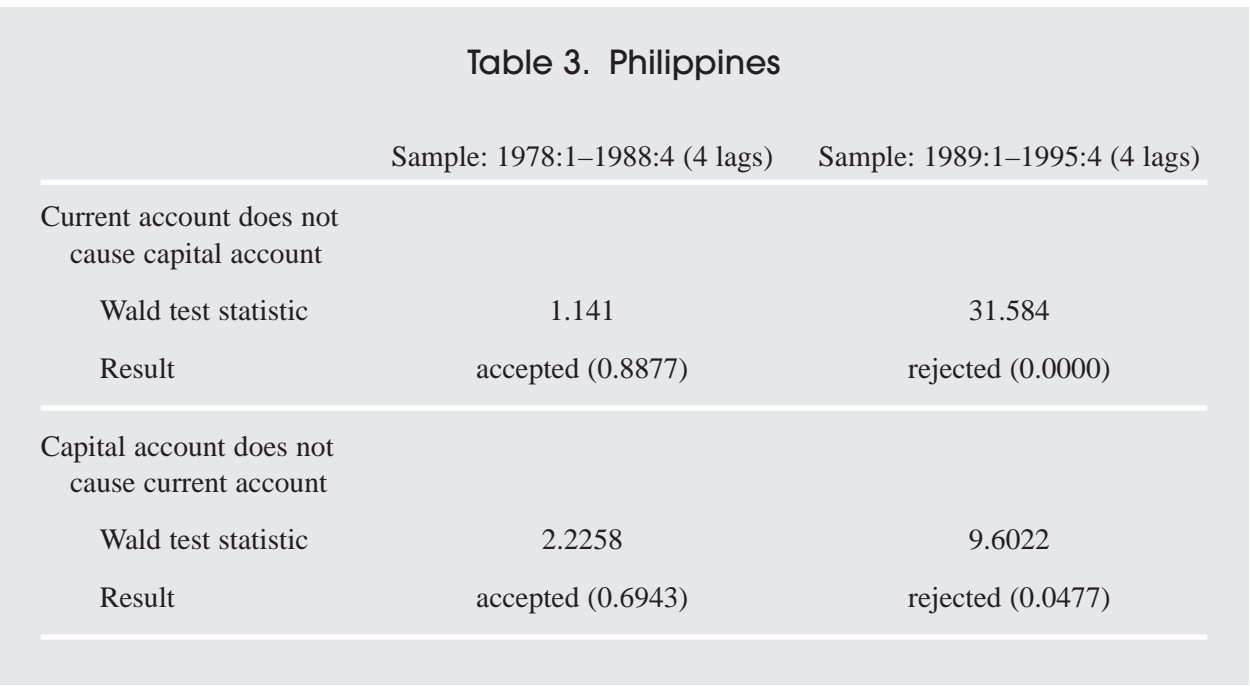

In Table 2, the causality tests for 1989-94 reveal that the capital account balance causes the current account balance but that the current account balance does not cause the capital account balance.

\section{Philippines}

Like many other developing countries, the Philippines reacted to the termsof-trade shocks in the 1970 s by borrowing extensively on world capital markets. But by the early 1980s, it had become increasingly difficult to finance current account deficits through external borrowing, and stabilization policies had to be implemented. The adjustment program that started in 1983 consisted of drastic cuts in fiscal expenditures and restrictive monetary policy. These policies effectively reduced domestic absorption, hence the reduction in external current account deficits.

As in the case of Mexico, the absence of foreign borrowing by the Philippines during the 1980s weakened the interaction between the current and capital accounts. Thus, the results of the causality tests for 1978-88 support the null hypothesis of no causality between the two accounts (Table 3). However, for the shorter period 1977-82, that is, excluding the period during which there was no access to the international capital markets, there is evidence of a causality running from the current account to the capital account. ${ }^{7}$

Once capital inflows to the Philippines resumed during the early 1990s, the authorities responded by pursuing sterilized intervention and fiscal tightening, while allowing the nominal exchange rate to appreciate despite the intervention efforts. The reserve requirement for banks, however, was reduced, with the

\footnotetext{
${ }^{7} \mathrm{~A}$ VAR model with two lags shows that the current account balance causes the capital account balance (probability of type $I$ error $=0.04$ ), while the capital account balance does not cause the current account balance (probability of type $I$ error $=0.11$ ).
} 
objective of lowering domestic interest rates. These stabilization measures were undertaken in tandem with the relaxation of controls on capital outflows and tightening of controls on capital inflows. The latter included a reduction in banks' minimum oversold foreign exchange positions as a ratio of unimpaired capital and central bank approvals for all forward transactions in foreign exchange. The surpluses in the capital account, combined with the policy responses, caused further current account deficits. In turn, the widening of current account deficits induced the monetary authorities to maintain tight monetary conditions. This policy reaction, however, failed to eliminate arbitrage opportunities, resulting in further capital inflows. Such feedback between the current account and the capital account is captured in the causality tests reported in Table 3.

\section{Thailand}

As in the case of the other countries, Thailand's policy response to the external shocks of the 1970s was to finance the current account deficits by foreign borrowing. Both the fiscal policy stance and the real exchange rate remained fairly constant. However, because of the strong fundamentals of the Thai economy, reflected in high economic growth rates, strong export performance, and modest domestic inflation, investor confidence did not change significantly during the debt crisis of 1982. Consequently, Thailand continued to have some limited access to the international capital markets. However, during this period, Thailand's fiscal deficits were financed mostly by internal noninflationary sources. As a result, foreign borrowing as a ratio of GDP declined steadily during 1981-87.

A VAR model with five lags was estimated for the period 1977-88. The results support both the hypothesis that the current account balance does not cause the capital account balance and the hypothesis that the capital account balance does not cause the current account balance (see Table 4). The tests for the restricted sample period 1976-82 show a causality running from the current account to the capital account. ${ }^{8}$

Beginning in the late 1980s, Thailand experienced a surge in capital inflows. The immediate response was to pursue sterilization and fiscal tightening, combined with structural reforms, including trade liberalization and liberalization of capital outflows. At the same time, banks' and finance companies' net foreign exchange positions limit as a ratio of capital was raised. Even though the pegged exchange rate system was maintained and the real exchange rate appreciated only moderately, the economy experienced increasingly large current account deficits. Credit restraint was insufficient to reduce the asset price bubble, and domestic demand continued to increase. Further tightening of credit encouraged more capital inflows, while the current account continued to deteriorate. In 1996, Thailand began to experience speculative attacks, which eventually led to the crisis of July 1997. The causality tests reported in Table 4 reveal strong feedback between large capital inflows and large current account deficits in Thailand for the period 1989-96.

\footnotetext{
${ }^{8}$ A VAR model with three lags shows that the current account balance causes the capital account balance (probability of type $I$ error $=0.08$ ), but the capital account balance does not cause the current account balance (probability of type $I$ error $=0.36$ ).
} 
Table 4. Thailand

Sample: 1977:2-1988:4 (5 lags) Sample: 1989:1-1996:4 (6 lags)

Current account does not cause capital account

Wald test statistic

Result

Capital account does not

cause current account

Wald test statistic

Result
7.554

accepted (0.1826)

3.9325

accepted (0.5592)
13.951

rejected $(0.0302)$

\subsection{8}

rejected (0.0749)

\section{Current Account Responses to Capital Inflows}

If a causal relationship is running from the capital account to the current account, or if the causality is running in both directions (feedback), a policy package aimed at reducing the current account deficit might have the opposite effect if it simultaneously stimulates capital inflows. To gain a better understanding of this relationship, this paper uses the orthogonalized impulseresponse function to analyze the current account responses to shocks in the capital account in the four countries during the post-globalization period. Starting from a situation in which the current account is in equilibrium, it is found that in all cases a positive once-and-for-all shock by one standard deviation in the capital account balance is followed almost immediately by a deterioration of the current account balance, as shown in Figure 1.

In the case of Argentina, the current account worsens immediately after the shock in the capital account takes place, reaching maximum deterioration during the second quarter. On average, it takes about 20 quarters for the current account to stabilize after a capital account shock. The situation is somewhat similar in the case of Mexico. A positive capital account shock is followed, after one quarter, by current account imbalances for the next 25 quarters.

For the Philippines and Thailand, positive shocks in the capital account are followed, after one quarter, by a worsening of the current account balance, and the current account remains in deficit for six quarters in the case of Philippines and four quarters in the case of Thailand. Afterward, the current account returns to its equilibrium, but with significant oscillations before stabilizing in the case of Thailand.

The differences in the current account responses between the two Latin American countries and the two Asian countries lie in the policies pursued. As discussed above, in Argentina and Mexico, the upsurge in capital inflows was followed almost immediately by large current account deficits owing to the drastic 
Figure 1. Current Account Responses to Shocks in Capital Account

Argentina

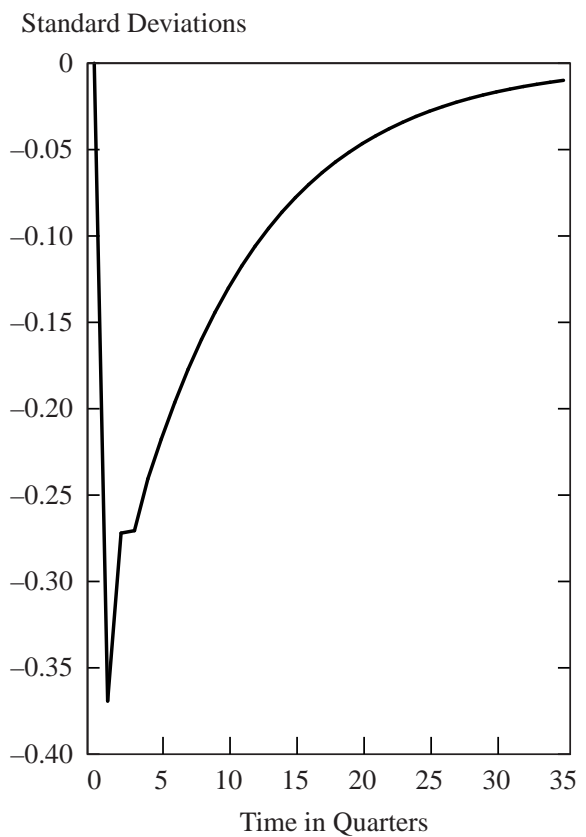

Philippines

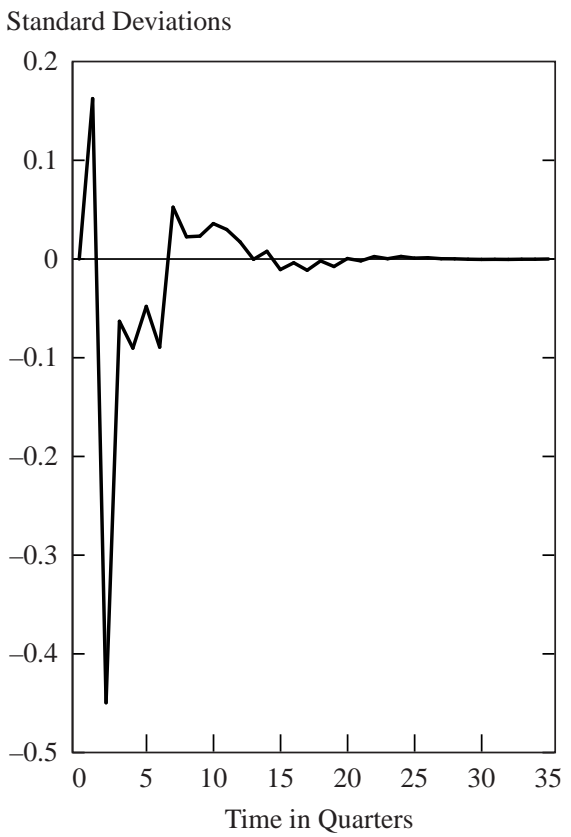

Mexico

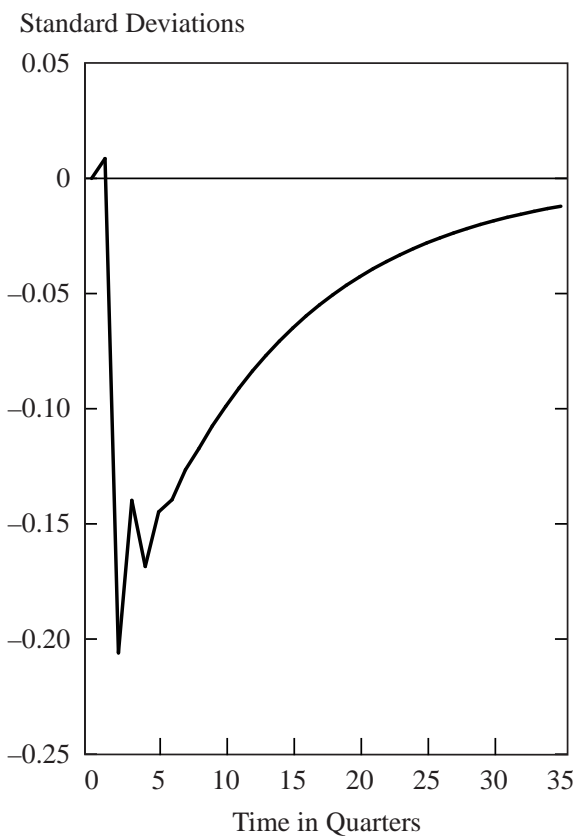

Thailand

Standard Deviations

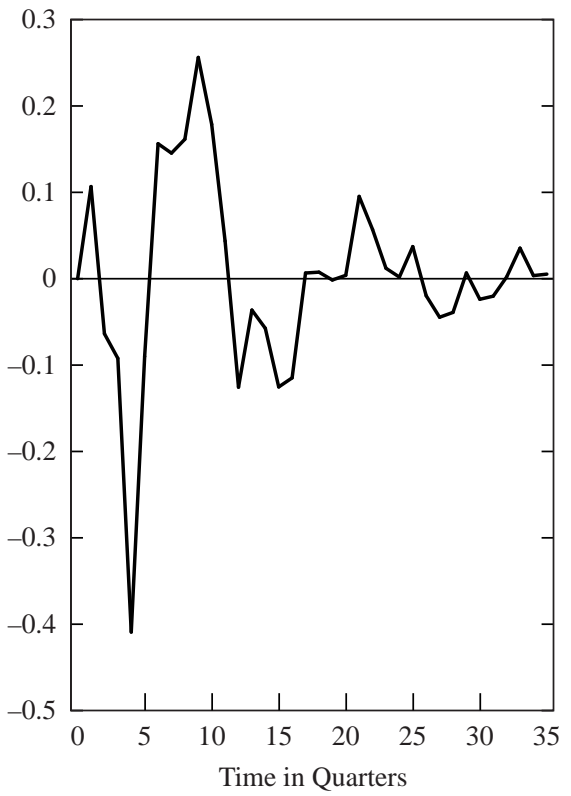


real exchange rate appreciation. By comparison, in the case of Thailand and, to a lesser extent, that of the Philippines, the appreciation of the real exchange rate was moderate. The current account was affected mostly by an expansion of domestic absorption stemming from loose liquidity conditions, a less direct channel than the change in relative prices.

\section{Conclusions}

Policy responses to large capital inflows in the four countries covered in the study were obviously not very successful. In 1994, the "honeymoon" of the market globalization era ended. First Mexico and then Argentina experienced serious macroeconomic problems associated with the reversal of capital flows. Thailand and the Philippines also experienced currency crises in 1997, in some aspects similar to the Mexican crisis. ${ }^{9}$ There is an extensive literature in the wake of the Asian crisis suggesting the need for strengthening the architecture of the international financial system and developing vulnerability indicators and early warning signals, ${ }^{10}$ which are beyond the scope of this paper. However, important lessons can be drawn from the experience regarding the design and conduct of macroeconomic policy.

In designing an appropriate policy to deal with external imbalances, it is important to identify the source of the imbalances to see if the imbalance in one account (current or capital) is causing the imbalance in the other account. This paper identifies four different possibilities in terms of causality: current account imbalance causing capital flows, capital account imbalance affecting the current account result, a two-way causality between the two accounts, and finally no causality between the two accounts. In particular, the empirical results show that, from the beginning of the rapid globalization of capital markets in the late 1980s until the mid-1990s, capital inflows have often caused current account deficits. These results would suggest that a capital account shock could create pressure in the foreign exchange market, driving the real exchange rate away from its longrun equilibrium value.

In this era of capital account openness, the nominal exchange rate should be made sufficiently flexible for market forces to establish equilibrium. ${ }^{11}$ This would isolate the monetary base from changes in net foreign assets, prevent speculation, and reduce further capital inflows by letting foreign investors bear higher exchange risks than they would in a fixed exchange rate system. Further, in the case where capital inflows cause current account deficits, tight monetary policy without sufficient complementary policies, particularly fiscal restraint, to reduce interest rate differentials, could worsen current account deficits because of an appreciation of the real exchange rate, if the nominal rate is allowed to appreciate.

\footnotetext{
${ }^{9}$ Some authors have relied on the multiple equilibrium hypothesis to explain the sudden reversal of capital flows. See, for example, Calvo (1995) and Cole and Kehoe (1996).

${ }^{10}$ See, for example, Camdessus (1998a, 1998b, and 1999), Fischer (1998), Goldstein (1998), IMF (1998a, 1998b, and 1998c), and Kaminsky, Lizondo, and Reinhart (1998).

${ }^{11}$ Interestingly, Goldstein (1998, p. 26) notes that "Hong Kong and Argentina have thus far fared better in the crisis than some of their neighbors not because they have currency boards but rather because they have gone farther in strengthening their banks and their liquidity defenses."
} 
This situation could become even worse if there is a two-way causality between the two accounts. Finally, the expansion of the monetary base stemming from large capital inflows could rapidly expand credit in the financial system, and this, in turn, could be the seed of a financial crisis, if it were to result in risk taking by financial institutions. As we all have begun to understand, strengthening reforms and surveillance of the financial system is necessary for the success of the adjustment process.

\section{REFERENCES}

Akaike, Hirotsugu, 1973, "Information Theory and an Extension of the Maximum Likelihood Principle," in Second International Symposium on Information Theory, ed. by B.N. Petrov and F. Csáki (Budapest: Akadémiai Kiadó), pp. 267-81.

Calvo, Guillermo A., 1995, "Varieties of Capital Market Crises," Inter-American Development Bank, Office of the Chief Economist, Working Paper No. 106 (Washington: IDB, August).

— Leonardo Leiderman, and Carmen M. Reinhart, 1993, "Capital Inflows and Real Exchange Rate Appreciation in Latin America: The Role of External Factors," Staff Papers, International Monetary Fund, Vol. 40 (March), pp. 108-51.

_ 1994, "The Capital Inflows Problem: Concepts and Issues," Contemporary Economic Policy, Vol. 12 (July), pp. 54-66.

— 1996, "Inflows of Capital to Developing Countries in the 1990s," Journal of Economic Perspectives, Vol. 10 (Spring), pp. 123-39.

Calvo, Guillermo, and Enrique Mendoza, 1996, "Petty Crime and Cruel Punishment: Lessons from the Mexican Debacle," American Economic Review, Papers and Proceedings, Vol. 86 (May), pp. 170-75.

Camdessus, Michel, 1998a, "Reflections on the Crisis in Asia," address to the Extraordinary Ministerial Meeting of the Group of 24, Caracas, Venezuela, February 7.

— 1998b, "Address to the Board of Governors of the Fund," Washington, October 6.

, 1999, "Looking Beyond Today's Financial Crisis: Moving Forward with International Financial Reform," address to the Foreign Policy Association, New York, February 24.

Cole, Harold, and Timothy Kehoe, 1996, "A Self-Fulfilling Model of Mexico's 1994-95 Debt Crisis," Journal of International Economics, Vol. 41 (November), pp. 309-30.

Dornbusch, Rudiger, Ilan Goldfajn, and Rodrigo O. Valdes, 1995, "Currency Crises and Collapses," Brookings Papers on Economic Activity: 2, Brookings Institution, pp. 219-70.

Fischer, Stanley, 1998, "The IMF and the Asian Crisis," delivered as the Forum Funds Lecture at UCLA, Los Angeles, March 20.

Goldstein, Morris, 1998, The Asian Financial Crisis: Causes, Cures, and Systemic Implications (Washington: Institute for International Economics).

Granger, C.W.J., 1969, "Investigating Causal Relations by Econometric Models and CrossSpectral Methods," Econometrica, Vol. 37 (July), pp. 424-38.

Hamilton, James D., 1994, Time Series Analysis (New Jersey: Princeton University Press).

International Monetary Fund, 1998a, World Economic Outlook, October 1998: A Survey by the Staff of the International Monetary Fund, World Economic and Financial Surveys (Washington).

— 1998b, World Economic Outlook, May 1998: A Survey by the Staff of the International Monetary Fund, World Economic and Financial Surveys (Washington). 
1998c, "Communiqué of the Interim Committee of the Board of Governors of the International Monetary Fund," Washington, April 16.

Judge, George G., W.E. Griffiths, R. Carter Hill, Helmut Lütkepohl, and Tsoung-Chao Lee, 1985, The Theory and Practice of Econometrics (New York: Wiley, 2nd ed.).

Kaminsky, Graciela, Saul Lizondo, and Carmen M. Reinhart, 1998, "Leading Indicators of Currency Crises," Staff Papers, International Monetary Fund, Vol. 45 (March), pp. 1-48.

Khan, Mohsin S., and Carmen M. Reinhart, eds., 1995, Capital Flows in the APEC Region, IMF Occasional Paper No. 122 (Washington: International Monetary Fund).

Montiel, Peter, 1995, "The New Wave of Capital Inflows to Developing Countries: Country Policy Chronologies" (unpublished; Washington: World Bank, April).

_ 1996 , "Policy Responses to Surges in Capital Inflows: Issues and Lessons," in Private Capital Flows to Emerging Markets After the Mexican Crisis, ed. by Guillermo A. Calvo, Morris Goldstein, and Eduard Hochreiter (Washington: Institute for International Economics), pp. 189-218.

—_ and Carmen M. Reinhart, 1997, "The Dynamics of Capital Movements to Emerging Economies During the 1990s" (unpublished; Williamstown, Massachusetts, and College Park, Maryland: Williams College and the University of Maryland, July).

Sachs, Jeffrey, Aaron Tornell, and Andrés Velasco, 1996, "The Collapse of the Mexican Peso: What Have We Learned?" Economic Policy: A European Forum (April), pp. 15-63.

Schadler, Susan, Maria Carkovic, Adam Bennett, and Robert Kahn, 1993, Recent Experience with Surges in Capital Inflows, IMF Occasional Paper No. 108 (Washington: International Monetary Fund). 